\title{
PANDANGAN TOKOH AGAMA TENTANG PENANGGUNGAN HUTANG PEWARIS OLEH AHLI WARIS (Studi Kasus di Desa Gonjak Kec. Praya Lombok Tengah)
}

\section{Halimah}

\begin{abstract}
Abstrak
Fokus kajian dalam penelitian ini adalah praktik penanggungan hutang pewaris oleh ahli waris di desa Gonjak, dan pandangan tokoh agama terhadap praktik penanggungan hutang pewaris. Realita praktik penanggungan ini masih ada yang tidak sesuai dengan syari'at hukum Islam karena masih ada para ahli waris yang membayar hutang pewaris dengan menggunakan harta pribadi ahli waris, dengan begitu para ahli waris berkesempatan untuk bisa mendapatkan harta pewaris yang ada. Metode penelitian yang peneliti gunakan dalam penelitian ini adalah: pendekatan kualitatif dengan menggunakan teknik pengumpulan data yakni metode observasi, wawancara dan dokumentasi. Adapun sumber datanya adalah data primer melalui interview warga dan tokoh agama, dan data sekunder melalui library research yang mempunyai hubungan dengan penelitian.

Penelitian ini menunjukkan bahwa dalam praktik penanggungan hutang pewaris oleh ahli waris pada dasarnya boleh dilakukan atau sah menurut hukum Islamkarena sudah sesuai dengan rukun dan syarat penanggungan (kafalah). Namun praktik yang dilakukan di masyarakat Gonjak masih belum terlakasana sesuai dengan hukum Islam sebagaimana pandangan para tokoh agama ada yang membolehkan dan tidak membolehkan. Tokoh agama yang membolehkan mengatakan bahwa praktik penanggungan hutang pewaris di desa Gonjak ini dibolehkan karena sudah sesuai dengan rukun dan syarat peanggungan (kafalah), Sementara pandangan tokoh agama yang tidak membolehkan mengatakan bahwa pembayaran yang ditunda-tunda bagi orang mampu itu tidak diperbolehkan karena awalnya berniat untuk menolong pihak yang berhutang (pewaris). Kedua, jika ahli waris berniat membantu dengan mengharapkan untuk mendapatkan sebagian harta pewaris maka itu tidak dibolehkan karena itu bukan termasuk sifat tolong menolong melainkan ingin mendapatkan keuntungan.
\end{abstract}

Kata Kunci: Penanggungan (kafalah), pewaris, ahli waris dan tokoh agama 


\section{A. Konteks Penelitian}

Kiprah manusia di dalam menjalankan perannya di dunia ini yakni dengan beribadah kepada Allah Swt. Selain dengan beribadah kepada Allah Swt. yang telah memberikan kehidupan serta pikiran sebagai tanda manusia merupakan makhluk ciptaan tuhan yang paling sempurna. Manusia juga diperintahkan untuk berbaur dan berinteraksi dengan sesama manusia sebagai tanda bahwa manusia merupakan makhluk sosial dimana yang dimaksud dengan makhluk sosial adalah manusia itu tidak akan pernah terlepas dari bantuan orang lain, baik kaya maupun miskin tetap saling membutuhkan.

Dari yang disyariatkan dalam Islam, terutama yang berhubungan dengan kegiatan ekonomi atau kebutuhan keluarga dalam sebuah rumah tangga, dalam memenuhi kehidupan sehari-hari setiap orang membutuhkan uang untuk kelangsungan hidupnya, dan dimana manusia juga di anjurkan untuk selalu berusaha mencari rizki yang halal untuk memenuhi kehidupan keluarga. Setiap manusia mempunyai kekurangan dan keterbatasan dalam berusaha sehingga membutuhkan bantuan orang lain dengan berbagai cara, baik dengan bantuan materi maupun dengan tenaga (jasa), seperti pinjam meminjam atau utang piutang. Sebagai makhluk sosial yang tidak bisa lepas dari bantuan orang lain, wajib hukumnya kita saling tolong menolong satu sama lain.

Dengan melangsungkan kehidupan dimasa sekarang ini kebanyakan orang melakukan transaksi hutang piutang, terutama orang yang sudah berkeluarga atau sudah berumahtangga.Dengan berjalannya umur yang semakin panjang, kematianpun menjadi semakin dekat. Sehingga hutangpun tidak bisa dilunasi, karena kehidupan di dunia tidak diketahui batasnya, akhirnya hutang dibawa sampai mati. Oleh sebab itu jika ada orang meninggal dunia dan tidak sempat membayar hutangnya, maka hutang tersebut harus dilunasi dengan harta peninggalannya, berdasarkan firman Allah Swt dalam al-Qur'an surat an-Nisa' ayat 11:

Artinya: (Pembagian-pembagian
tersebut di atas) sesudah dipenuhi
wasiat yang ia buat atau (dan)
sesudah dibayar hutangnya.
Dari ayat di atas menjelaskan bahwa apabila seseorang meninggal masih memiliki hutang maka hutang mayat tersebut harus dilunasi dengan harta peninggalan sebelum di bagi ke ahli waris.

Dalam hukum Islam telah disebutkan bahwa kewajiban ahli waris terhadap pewaris adalah pertama, mengurus jenazah sampai penyelesaian pemakaman, 
kedua, membayar semua hutang mayat, ketiga, membayar wasiat mayat. ${ }^{1}$ Tetapi dalam hal pengurusan jenazah dan penyelesaian hutang mayat mayoritas masyarakat Gonjak tidak secara lansung memakai harta peninggalannya, sehingga apabila orang yang meninggal dunia meninggalkan hutang dan harta peninggalan berupa uang tidak mencukupi untuk melunasinya. Maka disinilah ahli waris bertindak dalam menanggung atau membayar hutang pewaris. Maka dari itu muncullah praktik penanggungan hutang pewaris. Dan penanggungan hutang pewaris ini sudah menjadi kebiasaan pada umumnya terutama masyarakat di desa Gonjak.

Di mana yang menjadi penanggung ini merupakan orang yang cakap bertindak untuk melakukan sesuatu perbuatan hukum sesuai dengan ketentuan syari'at (yaitu baligh, berakal, hadir, dan atas kesukarelaannya sendiri). Sebagai mana dalam hadis telah dipraktikkan oleh salah satu sahabat Nabi Saw yang artinya.:

Dari jabir r.a. ia berkata. "telah meninggal dunia seorang laki-laki diantara kami, lalu kami memandikannya, mewangikannya dan mengkafaninya, kemudian kami membawa kehadapan Rasulullah

${ }^{1}$ Moh. Muhibbin, Abdul Wahid, Hukum Kewarisan Islam Sebagai Pembaruan Hukum Positif di Indonesi, (Jakarta: Sinar Grafika, 2011), h. 51.
Saw. lalu kami berkata, "hendaklah baginda menyalatkan orang ini, "kemudian beliau melangkah beberapa langkah lalu bersabda. "Apakahjenazahinipunyatanggungan hutang?" kami menjawab "dua dinar.” maka beliau pergi, kemudian Abu Qatadah menanggung hutang dua dinar itu, lalu kami datang lagi kepada Rasulullah Saw.dan Abu Qatadah berkata,"hutang dua dinar itu adalah menjadi tanggungan saya”, maka Rasulullah Saw. bersabda "tetapkah (benar-benarkah) engkau menanggung hutang itu?" dan si jenazah bebas dari padanya. "Abu Qatadah menjawab, "ya” lalu Rasulullah Saw. menyalatkan jenazah itu. (HR. Ahmad, Abu Dawud, dan Nasa'i). ${ }^{2}$

Hadits di atas menjelaskan bahwa hutang seseorang kepada orang lain itu tetap harus dibayar meskipun orang yang meninggal itu tidak memiliki harta peninggalan dan belum sempat membayar hutang.

Menurut pengamatan peneliti, di dalam hukum Islam menanggung hutang orang yang telah meninggal terjadi apabila si berutang tidak mampu membayar dengan harta peninggalannya. Padahal sudah dijelaskan dalam al-Qur'an secara tegas sebagaimana telah dicantumkan di atas pada surat an-Nisa' ayat 11 .

${ }^{2}$ Ibnu Hajar Al-Asqalani, Terjemah Bulughul Maram (Hukum ibadah dan Muamalah), (Surabaya: Gitamedia Press, 2006), h. 421. 
Bahkan dalam akad penanggungan ini, antara pihak penanggung dengan pihak ketiga yang memberi hutang membuat persyaratan mengenai waktu untuk melunasi utang tersebut. Jika dilihat dari jumlah harta peninggalan yang berutang sudah mencukupi untuk pembayarannya, kenapa juga pelunasannya ditundatunda.

"Menunda pembayaran bagi orang yang mampu adalah suatu kedzalaiman dan bilamana seseorang diantara kalian diminta untuk mengalihkan hutang kepada orang yang mampu, maka hendaklah dia menerimanya”.(HR. Bukhari Muslim) ${ }^{3}$

Artinya disini bahwa jika memang dengan harta peninggalan bisa melunasi hutang si pewaris tidak semestinya hutang tersebut ditanggung dan hal itu yang membuat pelunasannya menjadi ditunda. Dari pengamatan observasi peneliti penduduk desa Gonjak mayoritas memeluk agama Islam dan secara umum kuat dalam melaksanakan syariat agama Islam. Di dalam melaksanakan syari'at agama Islam disini terdapat para tokoh agama (Tuan guru) yang bertugas untuk membina dan membimbing umat Islam baik dalam masalah keagamaan maupun sosial kemasyarakatan, dengan cara berdakwah atau mengadakan pengajian umum untuk mengembangkan ilmunya sebagai penegak Islam di dalam masyarakat yang dimana kemampuannya dibutuhkan sebagai pilar utama bagi umat muslim demi mencapai suatu tujuan hidup untuk mendapatkan keselamatan dunia dan akhirat.

Berangkat dari uraian di atas, peneliti tertarik untuk mengkaji tentang "Pandangan Tokoh Agama Tentang Penanggungan Hutang Pewaris Oleh Ahli Waris (Studi kasus di Desa Gonjak, Praya, Lombok Tengah)".

\section{B. Kerangka Teoretik}

\section{Penanggungan}

Penanggungan dalam KUH Perdata Pasal 1820 menyebutkan, bahwa penanggungan adalah "suatu persetujuan dengan mana seorang pihak ketiga, guna kepentingan si berpiutang, mengikatkan diri untuk memenuhi perikatannya si berutang manakala orang ini sendiri tidak memenuhinya. ${ }^{4}$

Sedangkan penangungan utang adalah perjanjian, yaitu perjanjian yang dibuat oleh seorang pihak ketiga (jadi bukan debitur yang berkewajiban untuk memenuhi suatu perikatan yang telah ada)

${ }^{4}$ R. Subekti, Hukum Perjanjian, (Jakarta: PT. Internusa, 1991), h. 14. 
dengan kreditur (yang berhak atas pemenuhan perikatan oleh debitur). ${ }^{5}$

Dalam perjanjian utang piutang, sering terjadi bahwa yang memberikan pinjaman (kreditur), selain meminta jaminan yang bersifat kebendaan (dalam syari'at Islam disebut dengan gadai) juga meminta jaminan perorangan yang sering diistilahkan dengan penanggungan utang yang di dalam istilah hukumnya disebut juga dengan bortocht atau guaranty (bahasa Belanda). ${ }^{6}$

a. Pengertian Kafalah

Dalam kamus istilah

Fiqih kafalah merupakan hal menanggung, atau penanggungan terhadap sesuatu, yaitu akad yang mengandung perjanjian dari seseorang yang padanya ada hak yang wajib dipenuhi terhadap orang lain, dan berserikat bersama orang lain dalam tanggung jawab terhadap hak itu dalam menghadapi seorang penagih (utang). ${ }^{7}$

Pada asalnya, kafalah adalah padanan dari dhaman, yang

${ }^{5}$ Gunawan Widjaja, Kartini Muljadi, (Seri HukumPerikatan) Penanggungan Utang dan Perikatan Tanggung Menanggung, (Jakarta: PT Raja Grafindo Persada, 2003), h. 14.

${ }^{6}$ Chairuman Pasaribu, Suhrawardi K. Lubis, Hukum Perjanjian Dalam Islam, (Jakarta: Sinar Grafika, 2004), h. 148.

7 M. Abdul Mujieb, et. al,Kamus Istilah Fiqih,(Jakarta: PT. Pustaka Firdaus, 1994), h. 148. berarti penjaminan sebagaimana tersebut di atas. Namun dalam perkembangannya, situasi telah mengubah pengertian ini. Kafalah identik dengan kafalah al-wajhi (personal guarantee, jaminan diri), sedangkan dhamman identik dengan jaminan yang berbentuk harta secara mutlak. ${ }^{8}$

Dari beberapa definisi di atas, dapat disimpulkan bahwa kafalah adalah jaminan dari penjamin (pihak ketiga), baik berupa jaminan diri maupun harta kepada pihak kedua sehubungan dengan adanya hak dan kewajiban pihak kedua tersebut kepada pihak lain (pihak pertama). Konsep ini agak berbeda dengan konsep rahn yang juga bermakna barang jaminan, namun barang jaminannya dari orang yang berhutang. Ulama madzhab fikih membolehkan kedua jenis kafalah tersebut, baik diri maupun barang. ${ }^{9}$

Sedangkan al-kafalah atau aldhaman sebagaimana dijelaskan oleh para ulama' adalah sebagai berikut:
a) Menurut Hasby Ash- shiddiqie, al-kafalah ialah:
b) "Menggabungkan dzimmah kepada dzimah yang lain dalam penagihan, dengan

${ }^{8}$ Adiwarman A. Karim, Ekonomi Islam: Suatu Kajian Kontemporer,(Jakarta: Gema Insani, 2001), h. 106.

${ }^{9} \mathrm{Ibid}, 107$ 
jiwa, utang, atau zat benda." 10

c) Menurut Mazhab Maliki alkafalah ialah:

d) "Orang yang mempunyai hak mengerjakan tanggungan pemberi beban serta bebannya sendiri yang disatukan, baik menanggung pekerjaan yang sesuai (sama) maupun pekerjaan yang berbeda."

e) Menurut mazhab Hambali bahwa yang dimaksud dengan kafalah adalah Iltizam sesuatu yang diwajibkan kepada orang lain serta kekelan benda tersebut yang dibebankan atau iltizam orang yang mempunyai hak menghadirkan dua harta (pemiliknya) kepada orang yang mempunyai hak. ${ }^{11}$ Setelah diketahui definisi-definisi kafalah atau dhaman menurut para ulama' diatas, kiranya dapat dipahami bahwa yang dimaksud dengan alkafalah atau al-dhaman ialah menggabungkan dua

${ }^{10}$ Abdul Rahman Ghazaly, dkk, Fiqh Muamalat, (Jakarta: Kencana Prenada Media Group, 2010),h. 205.

${ }^{11}$ Sohari Sahrani, Ru'fah Abdullah, Fikih Mu'amalah,(Bogor: Ghalia Indonesia, 2011), h. 245 beban (tanggungan) dalam permintaan dan utang.

b. Dasar Hukum Kafalah

Terkait dengan legalitas akad kafalah, ulama' fiqih menggunakan dalil dari QS. Yusuf ayat 72:

Dasar hukum kafalah yang kedua adalah sunnah (hadits) yang artinya:

"Telah meninggal dunia seorang laki-laki diantara kami, lalu kami membawanya kehadapan Rasulullah Saw. lalu kami berkata, "hendaklah baginda menyalatkan orang ini, "kemudian beliau melangkah beberapa langkah lalu bersabda. "Apakah jenazah ini punya tanggungan hutang?" kami menjawab "dua dinar." maka beliau pergi, kemudian Abu Qatadah menanggung hutang dua dinar itu, lalu kami datang lagi kepada Rasulullah Saw.dan Abu Qatadah berkata,"hutang dua dinar itu adalah menjadi tanggungan saya", maka Rasulullah Saw. bersabda "tetapkah (benar-benarkah) engkau menanggung hutang itu?" dan si jenazah bebas dari padanya. "Abu Qatadah menjawab, "ya" lalu Rasulullah Saw. menyalatkan jenazah itu. (HR. Ahmad, Abu Dawud, dan Nasa'i). ${ }^{12}$

${ }^{12}$ IbnuHajar Al-Asqalani, Terjemah Bulughul Maram (Hukum ibadah dan Muamalah), (Surabaya: Gitamedia Press, 2006), h. 421 . 
c. Rukun dan Syarat Kafalah (Dhaman)

Ada beberapa rukun dan syarat yang harus dipenuhi dalam transaksi kafalah:

1. Kafil, yaitu orang yang berkewajiban melakukan tanggungan (makful bihi). kafil disyaratkan orang dewasa (baligh) berakal, berhak penuh untuk bertindak dalam urusan hartanya, dan dilakukan dengan kehendak sendiri. Kafil tidak boleh orang gila dan juga anak kecil sekalipun ia telah dapat membedakan sesuatu (tamyiz). ${ }^{13}$

2. Makful lahu yaitu orang yang berpiutang, syaratnya ialah bahwa yang berpiutang diketahui dan dikenal oleh orang yang menjamin. Hal ini supaya lebih mudah dan disiplin.

3. Makful'anhu adalah orang yang berutang, yaitu orang yang ditanggung. Tidak disyaratkan baligh, berakal, kehadiran dan kerelaannya dengan kafalah. ${ }^{14}$

4. Makful bihi (objek jaminan) adalah utang, barang

${ }^{13}$ Abdul Rahman Ghazaly, dkk, Fiqh Muamalah, h. 206.

${ }^{14}$ Sohari Sahrani, Ru'fah Abdullah, Fikih Mu’amalah, h. 247. atau orang, disyaratkan dapat diketahui dan tetap keadaannya. ${ }^{15}$ Objek pertanggungan harus bersifat mengikat terhadap diri tertanggung, dan tidak bisa dibatalkan tanpa adanya sebab syar'i. selain itu, objek tersebut harus merupakan tanggung jawab penuh pihak tertanggung.

5. Lafaz, yaitu lafaz yang menunjukkan arti menjamin, tidak digantungkan kepada sesuatu dan tidak berarti sementara. ${ }^{16}$ akad kafalah bisa diekspresikan dengan ungkapanyang menyatakan adanya kesanggupan untuk menanggung sesuatu, sebuah kesanggupan untuk menunaikan kewajiban. Seperti ungkapan "Aku akan menjadi penjaminmu" atau "saya akan menjadi penjamin atas kewajibanmu terhadap seseorang" atau ungkapan lain yang sejenis. ${ }^{17}$

\section{d. Macam-macam Kafalah}

Secara garis besar kafalah dibagi menjadi dua bagian yaitu:

${ }^{15}$ Ibid,h. 247.

${ }^{16}$ Abdul Rahman Ghazaly, dkk, Fiqh Muamalah, h. 207.

${ }^{17}$ Dimyauddin Djuwaini, Pengantar Fiqih Muamalah, (Yogyakarta: Pustaka Pelajar, 2010), h.248- 249. 
1. Kafalah dengan jiwa disebut juga dengan kafalahbi al-wajhi, yaitu adanya keharusan pada pihak penjamin (kafil) untuk menghadirkan orang yang ia tanggung kepada orang yang ia janjikan tanggungan (makful lahu/orang yang berpiutang).

2. Kafalah harta, yaitu kewajiban yang harus dipenuhi oleh kafil dengan pembayaran (pemenuhan) berupa harta. Kafalah dengan harta ini ada tiga macam, yaitu: pertama, Kafalah bi al-dayn. Yaitu, kewajiban membayar utang yang menjadi beban orang lain. Kedua, Kafalah dengan penyerahan benda (materi), yaitu kewajiban menyerahkan bendabenda tertentu yang ada ditangan orang lain, seperti, menyerahkan barang jualan kepada pembeli, mengembalikan barang yang dighasab dan sebagainya, disyaratkan benda tersebut yang dijamin untuk ashil seperti dalam kasus ghasab.

3. Kafalah dengan 'aib, yaitu menjamin barang, maksudnya bahwa barang yang didapati tersebut terdapat masalah ('aib) dan cacat bahaya karena waktu yang terlalu lama atau karena hal-hal lain. ${ }^{18}$

\section{Hukum Waris Islam}

a. Pengertian Hukum Waris Islam Dalambeberapaliteraturhukum Islam ditemui beberapa istilah untuk menamakan hukum waris Islam, seperti fiqih mawaris, ilmu faraidh, dan hukum kewarisan. Perbedaan dalam penamaan ini terjadi karena perbedaan arah yang dijadikan titik utama dalam pembahasan. Dalam kompilasi hukum Islam (KHI) dinyatakan bahwa hukum waris adalah hukum yang mengatur tentang pemindahan hak pemilikan harta peninggalan (tirkah) pewaris. ${ }^{19}$

Dalam istilah fiqih Islam, kewarisan (al-mawarits-kata tunggalnya al-mirats), lazim juga disebut dengan faraidh, jamak dari kata fardh dengan makna ketentuan (takdir). "al-fardh" dalam terminologi syar'i ialah bagian yang telah ditentukan untuk ahliwaris. Ilmu yang membahasperihal kewarisan umum dikenal dengan sebutan ilmu kewarisan(ilmu- mirats/al mawarist) atau ilmu faraidh. ${ }^{20}$ h. 209 .

${ }^{18}$ Abdul Rahman, dkk, Fiqh Muamalah,

${ }^{19}$ Moh. Muhibbin, Abdul Wahid, Hukum Kewarisan Sebagai Pembaruan Hukum Positif di Indonesia, (Jakarata: Sinar Grafika, 2001),h. 5 .

${ }^{20}$ Muhammad Amin Summa, Hukum Keluarga Islam Di Dunia Islam, (Jakarta: PT. 
Hukum waris menurut konsepsi hukum perdata barat yang bersumber pada BW, menurut Pitlo dalam buku Eman Suparman. Hukum waris adalah kumpulam peraturan yang mengatur hukum mengenai kekayaan karena wafatnya seseorang, yaitu mengenai pemindahan kekayaan yang ditinggalkan oleh si mati dan akibat pemindahan ini bagi orang-orang yang memperolehnya, baik dalam hubungan antar mereka dengan mereka, maupun dalam hubungan antara mereka dengan pihak ketiga. Pada dasarnya proses beralihnya harta kekayaan seseorang kepada ahli warisnya, yang dinamakan pewarisan, terjadi hanya karena kematian. Oleh karena itu, pewarisan baru akan terjadi jika terpenuhi tiga persyaratan, yaitu:

1) Ada orang yang meninggal dunia;

2) Ada seseorang yang masih hidup sebagai ahli waris yang akan memperoleh warisan pada saat pewaris meninggal dunia;

3) Ada sejumlah harta kekayaan yang ditinggalkan pewaris. ${ }^{21}$

Mengenai dasar hukum kewarisan disini terdapat dalam alQur'an dalam surat an-Nisa' ayat 7,

Raja Grafindo Persada. 2005), h. 108.

${ }^{21}$ Suparman, Eman, Hukum Waris Indonesia Dalam Persfektif Islam, Adat, Dan BW (Bandung: PT, Refika Aditama, 2005), h. 25.
$11,12,176$, dan surat-surat lainnya. Sejumlah ketentuan lainnya diatur dalam hadis, dan sejumlah ketentuan lainnya dalam ijma' dan ijtihad para sahabat, imam mazhab, dan para mujtahid lainnya. ${ }^{22}$ Sehubungan dengan pembahasan hukum waris, yang menjadi rukun waris mewarisi ada 3, yaitu: harta peninggalan (tirkah),pewaris (muwaris), dan ahli waris. ${ }^{23}$

b. Harta Peninggalan (Tirkah) dan Sebab-Sebab Mendapat Warisan Tirkah adalah sesuatu yang ditinggalkan pewaris, baik berupa harta benda dan hak-hak kebendaan atau bukan hak kebendaan.Dengan demikian, setiap sesuatu yang ditinggalkan oleh orang yang mati, menurut istilah jumhur fuqaha dikatakan sebagai tirkah, baik yang meninggal itu mempunyai utang-piutang 'ainiyah atau shahshiyah. Utang-piutang 'ainiyah adalah utang-piutang yang ada hubungannya dengan harta benda, seperti gadai,segala sesuatu yang berhubungan dengan barang yang digadaikan.Adapun yang dimaksud dengan utang-piutang shahshiyah adalah uatng-piutang yang berkaitan

${ }^{22}$ Otje Salman, Mustofa Haffas, Hukum Waris Islam(Bandung: Refika Aditama, 2002), h. 3 .

${ }^{23}$ Moh. Muhibbin, Abdul Wahid, Hukum Kewarisan, h. 17, 
dengan dengan kreditur, seperti qiradh, mahar dan lain-lain. ${ }^{24}$

Menurut Muhammad Jawad Mughniyah, yang dimaksud dengan harta peninggalan mayit adalah halhal berikut ini:

1) Segala sesuatu yang dimilikinya sebelum meninggal, baik berupa benda maupun hutang.

2) Hak-hak yang menjadi miliknya karena kematiannya, misalnya diyat (denda) bagi pembunuhan secara tidak sengaja atau sengaja atas dirinya. ${ }^{25}$

3) Harta yang dimilikinya sesudah dia meninggal, seperti binatang buruan yang masuk dalam perangkap yang dipasangnya ketika dia masih hidup.

Apabila dianalisis ketentuan hukum waris Islam, yang menjadi sebab seseorang itu mendapatkan warisan dari si mayat dapat diklasifikasikan sebagai berikut:

1) Karena ada hubungan perkawinan

Seseorang dapat memperoleh harta warisan (menjadi ahli waris) disebabkan adanya hubungan perkawinan antara si mayit denangan seseorang tersebut, yang termasuk dalam

${ }^{24}$ Beni Ahmad Saebani, Fiqih Mawaris,(Bandung:CV. Pustaka Setia.2009), h. 15 .

${ }^{25}$ Muhammad Jawad Mughniyah, Fiqih Lima Mazhab, (Jakarta: Penerbit Lentera, 2008), h. 535. klasifikasi ini adalah: suami, istri dari si mayit.

2) Karena adanya hubungan darah (nasab)

Seseorang dapat memperoleh harta warisan (menjadi ahli waris) disebabkan adanya hubungan nasab atau hubungan darah/ kekeluargaan dengan simayat, yang termasuk dalam klasifikasi ini sperti: ibu, bapak, kakek, nenek, anak, cucu, sudara, anak saudara, dan lainlain. ${ }^{26}$

3) Karena memerdekan budak (wala')

Seseorang mendapat warisan karena kekerabatan menurut hukum yang timbul karena membebaskan budak, sekalipun diantara mereka tidak ada hubungan darah.

4) Hubungan sesama Islam.

Hubungan sesama Islam yang dimaksud disini seseorang meninggal dunia tidak memiliki ahli waris sama sekali, maka harta warisannya diserahkan kepada Baitul Maal, dan lebih lanjut akan dipergunakan untuk kepentingan kaum muslimin. ${ }^{27}$

Sementara hal-hal yang menyebabkan ahli waris kehilangan hak mewarisi atau terhalang mewarisi
${ }^{26}$ Ibid, h. 535 .

${ }^{27}$ Ibid, h. 535 
adalah sebagai berikut: Perbudakan, Pembunuhan, Berlainan agama. ${ }^{28}$

1) Perbudakan

Status seorang budak tidak dapat menjadi ahli waris, karena dipandang tidak cakap mengurus harta dan telah putus hubungan kekeluargaan dengan kerabatnya.

2) Pembunuhan

Para ahli hukum Islam sepakat bahwa tindakan pembunuhan yang dilakukan oleh ahli waris terhadap pewarisnya, pada prinsipnya menjadi penghalang baginya untuk mewarisi harta warisan pewaris yang dibunuhnya. Berdasarkan kepada hadis Nabi Muhammad Saw. Dari Abu Hurairah menurut riwayat Abu Daud dan Ibnu Majah yang mengatakan bahwa, "Seseorang yang membunuh tidak berhak menerima warisan dari orang yang dibunuhnya."

3) Berlainan Agama

Berlainan agama maksudnya adanya perbedaan agama yang menjadi kepercayaan antara orang yang mewarisi dengan orang yang mewariskan. Ketentuan ini didasarkan pada hadis Nabi Muhammad Saw. Dari ibn Zaid menurut riwayat

${ }^{28}$ Moh. Muhibbin, Hukum Kewarisan Islam, h. 75 .
al-Bukhari, Muslim, Abu Daud, Tirmidzi dan Ibnu Majah yang artinya:

"Seseoarang muslim tidak menerima warisan dari yang bukan muslim, begitupula sebaliknya seseorang bukan muslim tidak menerima warisan dari seseorang muslim.”29

c. Ahli Waris dan Pewaris (Muwaris)

Kata "ahli waris" yang secara bahasa berarti keluarga tidak secara otomatis ia dapat mewarisi harta peninggalan pewarisnya yang meninggal dunia. Karena kedekatan hubungan kekeluargaan. Ahli waris ialah orang yang bernisbah (memiliki akses hubungan) kepada si mayit karena ada salah satu dari beberapa sebab yang menimbulkan kewarisan. ${ }^{30}$

Ahli waris adalah orang-orang yang berhak menerima harta peninggalan orang yang meninggal, baik karena hubungan keluarga, maupun karena memerdekan hamba sahaya (wala') ${ }^{31}$

Apabila dicermati, ahli waris ada dua macam, yaitu:

1) Ahli waris nasabiyah, yaitu ahli waris yang hubungan

${ }^{29}$ Ibid, h. 78.

${ }^{30}$ Muhammad Amin Summa, Hukukm Keluarga, h. 113.

${ }^{31}$ Dian Khairul Umam ,Fiqih Mawaris (Bandung:Pustaka Setia), h.44. 
kekeluargaan timbul karena hubungan darah.

2) hli waris sababiyah, yaitu hubungan kewarisan yang timbul karena suatu sebab tertentu, yaitu: perkawinan yang sah dan memerdekan hamba sahaya. ${ }^{32}$

Adapun penggolongan ahli waris ini dapat kita golongkan menjadi dua yakni ahli waris dari golongan laki-laki dan ahli waris dari golongan perempuan. Pertama, ahli waris (yaitu orang yang berhak mendapatkan warisan) dari kaum laki-laki ada sepuluh: 1) anak lelaki, 2) cucu lelaki, 3) ayah, 4) kakek, 5) saudara lelaki dari arah manapun, 6) anak lelaki dari saudara laki, 7) paman, 8)anak paman, 9)suami, 10) tuan yang telah memberi kenikmatan. Kedua, ahli waris dari kaum wanita ada tujuh: 1)anak perempuan, 2) anak perempuan dari anak lelaki, 3) ibu, 4) nenek, 5)saudara perempuan, 6)isteri, 7) bekas tuan perempuan. Pewaris yaitu orang yang meninggal dunia atau orang yang meninggalkan harta kepada orang-orang yang berhak menerimanya sesuai dengan syariat Islam. ${ }^{33}$

Bagi pewaris berlaku ketentuan bahwa harta yang ditinggalkan

${ }^{32}$ Rafiq Ahmad, Fiqih Mawaris (Jakarta: Raja Grafindo Persada, 2001), h. 59.

${ }^{33}$ Labib Mz. Harniawati, Risalah Fiqih Islam (Surabaya: Bintang Usaha Jaya. 2006), h. 556. miliknya dengan sempurna, dan ia benar-benar telah meninggal dunia, baik menurut kenyataan maupun menurut hukum. Kematian pewaris menurut para ulama' fiqih dibedakan menjadi 3 macam, yakni:

1) Mati haqiqy (sejati), ialah kematian yang dapat disaksikan oleh panca indra.

2) Mati hukmy, adalah kematian yang disebabkan adanya putusan hakim, baik orangnya masih hidup maupun sudah mati.

3) Mati taqdiry, adalah kematian yang didasarkan pada dugaan yang kuat bahwa orang yang bersangkutan telah mati. ${ }^{34}$

\section{d. Utang Pewaris}

Utang adalah tanggungan yang harus diadakan pelunasannya dalam suatu waktu tertentu. Kewajiban pelunasan utang timbul sebagai prestasi (imbalan) yang telah diterima oleh si berutang. Apabila seseorang yang meninggal telah meninggalkan utang kepada seseorang, maka seharusnya utang tersebut dibayar dilunasi terlebih dahulu dari harta peninggalan simayat sebelum harta peninggalan tersebut dibagikan kepada ahli warisnya.

Eman Suparman mengatakan dalam bukunya bahwa para ahliwaris bertanggung jawab untuk melunasi hutang-hutang pewaris dilunasi

${ }^{34}$ Otje Salman, Mustofa Haffas, Hukum Waris, h. 5. 
dengan harta peninggalannya. Karena itu, harta peninggalan pewaris baru akan dibagi setelah semua hutang-hutang tersebut dilunasi. Biaya penguburan merupakan salah satu hutang yang harus diutamakan pelunasannya. Para ahli hukum Islam mengelompokkan utang seseorang itu kepada dua kelompok: utang terhadap sesama manusia ("dain al'ibad), dan utang terhadap Allah (dain Allah). ${ }^{35}$

Utang terhadap sesama manusia, apabiladilihatdarisegipelaksanaannya dapat dipilah kepada:

1) Utang yang berkaitan dengan persoalan keharta bendaan (dain 'ainiyah). Seperti gadai.

2) Utang yang tidak berkaitan dengan persoalan kehartabendaan (dain mutlaqah).

3) Utang yang tidak berkaitan dengan persoalan kehartabendaan ini dilihat dari segi waktu pelaksaannya dapat pula dikelompokkan kepada:

a) Utang mutlaqah apabila dilakukan pada waktu si pewaris dalam keadaan sehat dan dibuktikan keabsahannya, disebut juga dengan "dain sihah"

${ }^{35}$ Suhrawardi K. Lubis dan Komis Simanjuntak, Hukum Waris Islam; Lengkap dan Praktis, (Jakarta: Sinar Grafika Offset, 2001), h. 45. b) Utang mutlaqah yang dilakukan pada waktu sipewaris dalam keadaan sakit, serta tidak pula didukung oleh bukti-bukti yang kuat, disebut juga dengan "dain marad"36

Apabila diperhatikan yang menjadi dasar hukum kewajiban membayar /melunasi utang ini dapat disandarkan kepada ketentuan hukum yang terdapat dalam surat anNisa ayat $11 . .^{37}$ Ada beberapa faktor yang mendorong seseorang untuk berhutang, antara lain adalah: ${ }^{38}$

a. Keadaan darurat, karena kesulitan hidup sehingga terpaksa berhutang atau meminjam dari orang lain.

b. Kecenderungan untuk menikmati kemewahan. Misalnya adalah ketika melihat orang lain memiliki barang-barang mewah, maka hati pun tergoda untuk ikut memilikinya.

c. Akibat kalah judi lalu seseorang berusaha menebus kekalahannya dengan jalan meminjam uang untuk meneruskan perjudiannya dengan harapan menang.

${ }^{36}$ Ibid, h. 46.

${ }^{37} \mathrm{Ibid}$, h. 46.

${ }^{38}$ Hamzah Ya'qub, Kode Etik Dagang Menurut Islam, Cetakan ketiga (Bandung: CV. Diponegoro, 1999), h. 212. 
Berkenaan dengan hutang kepada sesama manusia, perbuatan tersebut dapat menimbulkan akibatakibat buruk antara lain seperti: ${ }^{39}$

a) Menggoncangkan fikiran, mengganggu ketenangan dan ketenteramanjiwa, sebagaimana hadits riwayat Ahmad dan lainlain yaitu Rasulullah saw telah memperingatkan, bahwa:"Jiwa orang mu'min tergantung kepada hutangnya, hingga hutang itu dilunasi."

b) Merugikan nama baik keluarga, karena terganggu oleh tagihantagihan hutang;

c) Hutang yang besar dapat menghambat usaha orang lain. Pihak yang memberi hutang dapat mengalami kemacetan usaha, karena kapitalnya tertahan di tangan orang yang berhutang;

d) Pada puncaknya, hutang besar yang tak sanggup dibayar dapat mendorong seseorang berbuat kejahatan, misalnya dengan mencuri, menipu, bunuh diri, dan sebagainya.

e) Hak dan Kewajiban yang Berkaitan dengan Harta Peninggalan Pewaris

Berkaitan dengan tarikah ada beberapa hak yang harus dipenuhisecara tertibsehingga apabila hak yang pertama, atau yang

${ }^{39}$ Ibid, h. 214 kedua menghabiskan segala tarikah, tidaklah lagi berpindah kepada hak-hak yang lain. Adapun hak-hak yang harus didahulukan dan harus dilaksanakan secara tertib sebelum para waris menerima bahagiannya adalah: ${ }^{40}$

1) Tajhiz atau biaya penyelenggaraan jenazah

Tajhiz ialah segala yang diperlukan oleh seseorang yang meninggal dunia mulai dari wafatnya sampaikepada penguburannya. Diantara kebutuhan tersebut antara lain: biaya memandikan, mengkafankan, menguburkan, dan segala yang diperlukan sampai diletakkannya ketempat yang terakhir.

2) Melunasi hutang

Hutang yang harus dibayar oleh orangyangmeninggal. Apabilasimayit mempunyai utang atau tanggungan belum dibayar ketika masih hidup didunia, baik yang berkaitan dengan sesama manusia maupun kepada Allah, untuk keperluan membayar hutang diambil dari pada tarikah sesudah diambil keperluan keperluan tajhiz.

Menurut pendapat Jumhur Fuqaha, bahwasanya hutanghutang pada Allah tidaklah gugur karena matinya orang yang belum membayar hutangnya, dan wajiblah

${ }^{40}$ Moh. Muhibbin, Hukum Kewarisan Islam, h.51. 
hutang-hutang itu ditunaikan sebelum menunaikan wasiatnya, walaupun tidak diwasiatkan untuk membayarnya. Menurut pendapat golongan Hanafiyah, hutang-hutang pada Allah seperti hutang zakat, kafarat, dan nazar, tidak diambil dari tarikah. Walaupun Jumhur Fuqaha sependapat dalam menetapkan bahwa hutang-hutang daripada Allah diambil dari tarikah dan didahulukan atas wasiat, namun mereka berbeda pendapat dalam tertib penunaiannya. Ada pula yang mengatakan bahwa: ${ }^{41}$

a. Hutang-hutang pada Allah didahulukan atas hutanghutang pada sesama manusia. Demikianlah mazhab syafi'iyah dan adludh-dhahir;

b. Hutang-hutang pada Allah dikemudiankan dari hutang pada semua manusia. Inilah madzhab malikiyah;

c. Hutang pada Allah dan hutang padahambayangtidakberpautan dengan benda, sama derajatnya dalam menunaikannya, dan dia dikemudiankandari hutang pada sesama hamba yang berpautan dengan benda. Inilah pendapat golongan Hambaliyah.

3) Melaksanakan atau menunaikan wasiat

Wasiat ialah pesan seseorang untuk memberikan sesuatu kepada orang lain setelah ia meninggal dunia.

${ }^{41} \mathrm{Ibid}, \mathrm{h} .53$.
Jika sebelum meninggal seseorang telah berwasiat, maka dipenuhilah wasiat itu dari harta peninggalannya dengan tidak boleh lebih dari $1 / 3$ harta bila dia mempunyai ahli waris dan jika dia akan berwasiat lebih dari $1 / 3$ harus mendapat persetujuan ahli warisnya.

\section{PEMBAHASAN}

\section{a. Analisis Praktik \\ Penanggungan Hutang Pewaris Oleh Ahli Waris di Desa Gonjak}

Sebagaimana yang telah diuraikan pada paparan data dan temuan diatas bahwa penanggungan hutang mayat di desa Gonjak dipengaruhi oleh kehendak dari para ahli waris sendiri. Penanggungan ini identik dengan penanggungan hutang dalam bentukuang. Pinjaman yang dilakukan oleh pihak peminjam asli (orang meninggal), adalah pinjaman berbentuk uang bukan berbentuk barang. Maka dari itu jika pinjaman uang hendaklah pengembaliannya dalam bentuk uang juga. Dalam akad perjanjian penanggungan yang dilakukan di desa Gonjak adalah dengan caralisan dan memakai surat resmi (tertulis). Oleh sebab itu perlu dibahas lebih lanjut dalam bab ini.

Secara umum penanggungan hutang mayat di desa Gonjak yang dapat ditanggung itu ada 2 golongan yakni, penanggungan hutang mayatyang meninggalkan 
harta peninggalan dan yang tidak meninggalkan harta peninggalan.

Salah satu transaksi yang dalam transaksi penanggungan hutang ini biasanya yang ditanggung adalah orang yang sudah mati/ hilang atau bisa juga orang yang pailit, seperti halnya hutang yang dibawa mati orang tua (ibu atau ayah), saudara atau anak. Sementara yang biasa menjadi pihak penanggung adalah sanak saudara/ keluarga terdekat dari mayat. Seperti yang telah dipaparkan pada bab sebelumnya bahwa transaksi menanggung hutang ini memang sudah ada sejak dulu zaman nabi sendiri sudah ada, sehingga wajarlah penanggungan itu masih dilakukan sampai sekarang.

Penanggungan ini adalah hal yang perlu dilakukan jika seseorang yang berhutang tidak mampu mebayar hutangnya maka penanggungan bisa dilakukan bagi orang yang mempunyai kemampuan dalam melunasi hutang tersebut. Hal ini merupakan suatu sifat toleransi yang ada pada diri manusia terutama bagi masyarakat yang ada di desa Gonjak. Mengenai pihak penanggung yang sifatnya adalah orang yang mampu dalam mengelola hartanya. Menurut peneliti disini orang yang mampu adalah orang yang benarbenar memilki harta sendiri dan dia berhak untuk mengelolanya.
Dalam melakukan penanggungan yang dilakukan oleh Desa Gonjak yang terutama bagi para ahli waris yang menanggung utang orang tuanya yang sudah meninggal maka itu adalah hal yang wajar dan itu merupakan kebaktian seseorang anak terhadap orang tua. Dan penanggungan ini biasa dilakukan pada saat orangtua sudah meninggal dunia. Wujud berbakti kepada orang tua yang meninggal dunia itulah yang menjadi dalih dilaksnakannya, karena pewaris merupakan orang yang telah merawat dan membesarkan mereka, ketika masih hidupnya pewaris sehingga kebutuhan para ahli waris yang ditinggalkan terpenuhi. Sebagaimana telah dijelaskan dalam hukum waris Islam bahwa tanggung jawab seorang ahli waris dapat ditemukan dalam surat al-Baqarah ayat 233 .

Menurut Muhammad Jawad Mughniyah yang dimaksud dengan harta peninggalan mayit adalah halhal berikut ini:

a. Segala sesuatu yang dimilikinya sebelum meninggal, baik berupa benda maupun hutang.

b. Hak-hak yang menjadi miliknya karena kematiannya, misalnya diyat(denda) bagi pembunuhan secara tidak sengaja atau sengaja atas dirinya.

c. Harta yang dimilikinya sesudah dia meninggal, seperti binatang 
buruan yang masuk dalam perangkap yang dipasangnya ketika dia masih hidup. ${ }^{42}$

Mengenai orang-orang yang dapat ditanggung, para ulama fikih menyatakan, bahwa pada dasarnya setiaporangdapatmenerimajaminan/ tanggungan tersebut. Mereka hanya berbeda pendapat mengenai orang yang sudah wafat (mati) yang tidak meninggalkan harta warisan.

Menurut pendapat Imam Malik dan Syafi'i, hal yang demikian boleh ditanggung. Alasannya adalah dengan berpedoman pada Hadis yang telah dipaparkan pada bab sebelumnya, tentang ketidaksediaan Nabi SAW. menshalatkan jenazah karena meninggalkan sejumlah hutang. Sedangkan Imam Hanafi menyatakan tidak boleh, dengan alasan bahwa tanggungan tersebut tidak berkaitan sama sekali dengan orang yang tidak ada. Berbeda halnya dengan orang yang pailit.

ketika si berhutang meninggal dunia, maka ahli waris yang wajib menanggung hutang-hutang yang masih ada. Seperti yang dilakukan kebanyakan orang muslim, khususnya yang ada di desa Gonjak dalam hal penanggungan hutang orang meninggal selain mengurus pemakaman mayat ahli waris juga

${ }^{42}$ Mughniyah Jawad Muhammad,Fiqih Lima Mazhab, (Jakarta: Penerbit Lentera, 2008), h. 531. harus mengurus hutang - hutang mayit.

Sebagaiman dalam hukum waris Islam bahwa terdapat hak-hak dan kewajiban ahli waris terhadap harta peninggalan pewaris:

a. Tajhiz atau biaya penyelenggaraan jenazah;

b. Melunasi hutang-hutang mayat;

c. Menunaikan hibah dan wasiat mayat. ${ }^{43}$

Islam adalah agama yang diturunkan Allah dengan penuh rahmat untuk alam semesta. Selain itu, Islam juga sangat menghargai dan melindungikepentingan manusia. Maka dari hal itu penaggungan utang tersebut boleh dilakukan selama transaksi tersebut disesuaikan dengan hukum yang ada. Supaya diantara pihak yang bertransaksi tidak ada yang merasa dirugikan.

Dari hasil observasi peneliti melihat si penanggung melakukan hal itu karena pihak penaggung tidak ingin saudara atau orang tua meninggal membawa hutang. Penanggungan ini juga sengaja dilakukan agar harta peninggalannya tetap dibagikan kepada ahli waris. Sehingga harta warisan tersebut tetap di terima oleh ahli waris.

Dalam menanggung hutang pewaris mereka sebagai ahli waris

${ }^{43}$ Moh. Muhibbin, Abdul Wahid, Hukum Kewarisan Islam Sebagai Pembaruan Hukum Positif Di Indonesia, (Jakarta: Sinar Grafika, 2011), h. 51. 
laki-laki atau ahli waris perempuan mengeluarkan sejumlah uangnya untuk membebaskan mayat dari beban hutang yang ada, disini juga termasuk poin penting ketika harta warisan tidak sama besar dengan jumlah uang yang dikeluarkan oleh ahli waris untuk biaya mulai dari tajhizsampai pelunasan hutang pewaris yang ditinggalkan tersebut.

Pada kasus yang sudah dijelaskan sebelumnya bahwa penduduk desa Gonjak mengatur harta peninggalan dengan mengikuti adat kebiasaan dari nenek moyang mereka. Semua yang berkaitan dengan harta peninggalan selain dari pemenuhan wasiat dan hibah, seperti penanggungan utang serta tahjiz mayit tidak diambil dari harta peninggalan. Namun semua itu merupakan tanggung jawab keluarga, karena menurut mereka hutang-hutang yang dimilki pewaris semasa hidupnya secara tidak lansung telah dihiwalahkan kepada mereka dengan kematian si pewaris.

Selanjutnya ditegaskan bahwa, dengan kewajiban para ahli waris untuk membayar hutang, dimanapun ahli waris berada tetap saja harus memikul tanggung jawab tersebut. Akibatya, menambahkan beban tanggung jawab lagi kepada ahli waris yang dekat dengan pewaris untuk mengeluarkan sejumlah uang yang disepakati.
Tetapi sering terjadi problema seperti ini pulalah yang memotivasi para penghulu dan pemuka masyarakat untuk membina dan memberikan kesadaran kepada masyarakat tentang nilai-nilai luhur yang terdapat dalam penanggungan utang pewaris. Sehingga sedikit demi sedikit kebiasaan menanggung hutang pewaris oleh ahli waris di desa Gonjak mulai berkurang.

\section{b. Analisis Pandangan Tokoh Agama Tentang Praktik Penanggungan Hutang Pewaris oleh Ahli Waris di Desa Gonjak.}

Dari hasil penelitian yang peneliti lakukan di desa Gonjak ini ternyata memiliki banyak aliran dan faham yang tentunya tidak bisa mencapai satu tujuan yang diinginkan sebagaimana mestinya. Namun perbedaan itu tidaklah sampai merusak hubungan masyarakat sebagai makhluk Allah Swt. dan menjauhkan antara masyarakat yang satu dengan dengan yang lainnya, justru dengan perbedaan itu membuat masyarakat lebih faham tentang bagaimana pendapat dan menghargai pendapat orang lain, walaupun pada dasarnya perbedaaan ituakan membuat masyarakatpanatik tentang sesuatu yang diyakininya, akan tetapi masyarakat desa Gonjak ini mampu mengendalikan dirinya agar tidak sampai terjadi hal-hal yang tidak diinginkan. 
Perbedaan pendapat merupakan salah satu permasalahan yang sangat erat dengan kehidupan dalam bermasyarakat dan perbedaan juga tidak pernah lepas dari kehidupan sehari-hari, walaupun terkadang permaslahan biasa membuat persaudaraan rapuh ataupun putus dengan sesama manusia lainnya. Dengan perbedaan juga kita akan saling kenal mengenal antara sesama dan saling tukar menukar pikiran maupun dalam hal pengetahuan.

Dalam masyarakat kita tidak pernah lepas dari masalah, akan tetapi bagaimana sulitnya permasalahan itu pasti ada jalan keluarnya atau titik terang. Bergitu juga dengan perbedaan pendapat yang terjadi di tengah masyarakat yang merupakan masalah bagi kita semua dalam menjalankan kewajiban kita dan merupakan salah satu tanggungjawab kita bagaimana menjaga hubungan yang baik dengan masyarakat yang lainnya.

\section{Adapun mengenai} dibolehkannya penanggungan utang pewaris yang mempunyai harta peninggalan ini disebabkan karena ini adalah kebiasaan masyarakat dalam berbakti kepada orang tua, meskipun orang tua tersebut sudah meninggal, yang diutamakan adalah pihak yang menanggung atau ahli waris sudah sanggup menanggung untuk melunasi utang tersebut.
Dan dalam akad perjanjian penanggungan juga tidak terdapat kesenjangan dalam hukum Islam karena kedua belah pihak sudah menyetujui secara lansung (saling berhadapan) persyaratan yang dibuat meskipun itu dilakukan dengan cara lisan.

Sebagaimana yang telah dipaparkan oleh TGH. Mukhtar Hamid dan TGH. Faharudin, selama rukun dan syarat dari penanggungan (kafalah) sudah terjalani sesuai syariat Islam maka transaksi penanggungan itu dibolehkan. Akad dalam penyelesaian transaksi penanggungan tersebut disepakati bersama antara pihak piutang dengan pihak yang menanggung. Dalam hal waktu pelunasannya sudah disetujui oleh pihak piutang yang dimana akadnya dilakukan secara lisan oleh kedua belah pihak. Sementara jika dilihat dari pandangan Ust. Marwi Husna, praktik penanggungan utang yang dilakukan oleh ahli waris di dalam meminta tempo waktu yang dimana dalam penanggungan tersebut masyakat desa Gonjak mengadakan pengunduran dalam melunasi yang sehingga terbentuk pembayaran yang seharusnya dibayar sesegera mungkin menjadi hal yang tertunda. Karena dalam salah satu syarat pihak yang menanggung (kafil) adalah orang yang mampu.Mampu disini menurut beliau adalah mampu dengan secara tunai untuk mebayar 
utang tersebut. Jadi disini menurut beliau hal ini bisa mengakibatkan terjadinya kelalaian bagi pihak yang menanggung. Berdasarkan dalam hadis Nabi Saw. Bahwa Nabi Muhammad tidak mau menshalatkan mayat yang masih mempunyai hutang.

Dengan demikian jelaslah bahwa terjadinya perbedaan pendapat diantara para tokoh agama terhadap penanggungan utang pewaris yang meninggalkan harta peninggalan disebabkan beda pemahaman dan keyakinan.

Menurut peneliti dari hasil analisis diatas menjelaskan bahwa penanggungan utang yang dilakukan oleh ahli waris terhadap pewaris yang meninggalkan harta peninggalan adalah sah-sah saja karena kedua belah pihak sama-sama menyetujui perjanjian tersebut. Akan tetapi dalam hal isi perjanjian itu tidak dibuat dengan jelas jangka waktu yang diminta. Hal ini menyebabkan pihak piutang menerima uangnya kembali tidak secara cepat. Jadi menurut peneliti adalah tidak sah karena dalam meminta jangka waktu untuk pelunasannya terlalu lama padahal pihak penanggung seharusnya mampu secara lansung untuk menanggung.

\section{PENUTUP}

\section{a. Kesimpulan}

Dari paparan dan penjelasanpenjelasan di atas, dapat ditarik kesimpulannya sebagai berikut:

1. Praktik pelaksanaan penanggungan utang pewaris terhadap ahli waris. Pelaksanaan penanggungan utang pewaris disini dilakukan oleh ahli waris sendiri, meskipun pewaris tersebut meninggalkan harta peninggalan. Sistem penanggungan yang dilakukan oleh pihak ahli waris di desa Gonjak memakai sistem hukum adat. Ahli warislah yang bertanggung jawab dalam penanggungan tersebut. Karena menurut desa Gonjak semua harta atau utang yang melekat pada diri pewaris itu adalah hak dan tanggung jawab ahli waris. Apabila harta yang ditinggal itu dibagikan ke ahli waris maka utang tersebut juga menjadi tanggung jawab ahli waris. Jadi bisa disimpulkan bahwa masyarakat desa Gonjak masih kuat menganut tradisi atau kebiasaan dalam melunasi utang pewaris.

2. Respons tokoh agama terhadap penanggungan utang yang dilakukan di desa Gonjak mempunyai dua pendapat yakni ada yang membolehkan dan ada 
yang tidak membolehkan, yang membolehkan berpendapat bahwa penaggungan utang pewaris yang meninggalkan hartapeninggalanitudibolehkan karena dalam penanggungan tersebut tidak ada unsur keterpaksaan dari pihak yang menanggung dan ini adalah sebuah tradisi yang dilakukan oleh desa Gonjak. Sedangkan perjanjian dalam meminta waktu tempo pembayaran itu juga merupakan akad yang sah dilakukan karena pihak berpiutang menerima perjanjian tersebut. Ini adalah pendapat dari TGH. Mukhtar Hamid yang mana pandangannya selaras dengan TGH. Faharudin. Sedangkan yang tidak membolehkan adalah Ust. Marwi Husna, beliau beralasan bahwa pihak yang ditanggungadalahorangmampu maka itu tidak diwajibkan untuk menanggung, apalagi hal penanggungan tersebut ada jangka waktu pembayarannya. Menurut beliau orang yang mampu itu adalah orang yang mempunyaiharta sendiridan dia secara lansung melunasi utang tersebut tanpa meminta waktu tempo pembayaran, seharusnya ini tidak boleh menunda-nunda pembayaran. Menurut analisis peneliti dari permasalahan diatas menjelaskan bahwa penanggungan utang yang dilakukan oleh ahli waris terhadap pewaris yang meninggalkan harta peninggalan adalah sahsah saja karena kedua belah pihak sama-sama menyetujui perjanjian tersebut. Mengenai kemampuan disana peneliti menganalisis bahwa mampu itu adalah tidak mesti harus dibayar secara lansung. Tetapi bagi seorang penanggung itu adalah hal yang sulit untuk melakukan trnasaksi tersebut, sehingga wajarlah pihak piutang memberikan jangka waktu pelunasan terhadap pihak penanggung.

\section{b. Saran-Saran}

1. Para tokoh agama setempat diharapkan untuk memberikan penyuluhan kepada masyarakat desa Gonjak dalam hal tanggung menanggung hutang orang meninggal (pewaris) yang dilakukan oleh ahli waris yang sesuai dengan apa yang disyari'atkan dalam Islam.

2. Bagi masyarakat desa Gonjak khususnya pihak yang berutang agar tidak melalaikan utangnya, sehingga utang tersebut tidak dibawa sampai mati. Dan bagi pihak yang menanggung apabila berniat untuk menanggung maka sebaiknya 
kewajiban melunasi hutang yang ditanggung/dijamin harus dilunasi secepatnya, agar pihak piutang (orang yang memberi utang) dapat segera menerima uangnya kembali.

\section{Daftar Pustaka}

Abdul Rahman Ghazaly, dkk, Fiqh Muamalat, (Jakarta: Kencana Prenada Media Group, 2010),

Adiwarman A. Karim, Ekonomi Islam: Suatu Kajian Kontemporer,(Jakarta: Gema Insani, 2001)

Beni Ahmad Saebani, Fiqih Mawaris,(Bandung:CV. Pustaka Setia.2009),

Chairuman Pasaribu, Suhrawardi K. Lubis, Hukum Perjanjian Dalam Islam, (Jakarta: Sinar Grafika, 2004),

Dian Khairul Umam ,Fiqih Mawaris (Bandung:Pustaka Setia)

Dimyauddin Djuwaini, Pengantar

Fiqih Muamalah, (Yogyakarta: Pustaka Pelajar, 2010),

Gunawan Widjaja, Kartini Muljadi, (Seri HukumPerikatan) Penanggungan Utang dan Perikatan Tanggung Menanggung, (Jakarta: PT Raja Grafindo Persada, 2003),

Hamzah Ya'qub, Kode Etik Dagang Menurut Islam, Cetakan ketiga
(Bandung: CV. Diponegoro, 1999),

IbnuHajar Al-Asqalani, Terjemah Bulughul Maram (Hukum ibadah dan Muamalah), (Surabaya: Gitamedia Press, 2006),

Ibnu Hajar Al-Asqalani, Terjemah Bulughul Maram (Hukum ibadah dan Muamalah), (Surabaya: Gitamedia Press, 2006),

Labib Mz. Harniawati, Risalah Fiqih Islam (Surabaya: Bintang Usaha Jaya. 2006),

Moh. Muhibbin, Abdul Wahid, Hukum Kewarisan Islam Sebagai Pembaruan Hukum Positif di Indonesi, (Jakarta: Sinar Grafika, 2011),

M. Nashiruddin al-Albani, Ringkasan Shahih Muslim Jilid 1, (Jakarta: Pustaka Azzam, 2007),

M. Abdul Mujieb, et. al,Kamus Istilah Fiqih,(Jakarta: PT. Pustaka Firdaus, 1994),

Moh. Muhibbin, Abdul Wahid, Hukum Kewarisan Sebagai Pembaruan Hukum Positif di Indonesia, (Jakarata: Sinar Grafika, 2001),

Muhammad Amin Summa, Hukum Keluarga Islam Di Dunia Islam, (Jakarta: PT. Raja Grafindo Persada. 2005), 
Muhammad Jawad Mughniyah, Fiqih Lima Mazhab, (Jakarta: Penerbit Lentera, 2008),

Moh. Muhibbin, Abdul Wahid, Hukum Kewarisan Islam Sebagai Pembaruan Hukum Positif Di Indonesia, (Jakarta: Sinar Grafika, 2011),

Mughniyah Jawad Muhammad,Fiqih Lima Mazhab, (Jakarta: Penerbit Lentera, 2008),

Otje Salman, Mustofa Haffas, Hukum Waris Islam(Bandung: Refika Aditama, 2002),
Rafiq Ahmad, Fiqih Mawaris (Jakarta: Raja Grafindo Persada, 2001),

R. Subekti, Hukum Perjanjian, (Jakarta: PT. Internusa, 1991),

Sohari Sahrani, Ru'fah Abdullah, Fikih Mu'amalah,(Bogor: Ghalia Indonesia, 2011),

Suparman, Eman, Hukum Waris Indonesia Dalam Persfektif Islam, Adat, Dan BW (Bandung: PT, Refika Aditama, 2005),

Suhrawardi K. Lubis dan Komis Simanjuntak, Hukum Waris Islam; Lengkap dan Praktis, (Jakarta: Sinar Grafika Offset, 2001) 